\title{
$\mathrm{ATSC}$ 신호 검출을 위한 스펙트럴 상관 밀도의 결합을 이용하는 스펙트럼 센싱
}

\section{Spectrum Sensing with Combining Spectral Correlation Density for ATSC Signal Detection}

\author{
유도식*, 임종태 ${ }^{* 0}$ \\ Do-Sik Yoo*, Jongtae Lim $^{* 0}$ \\ 요 약
}

본 논문에서는 스펙트럴 상관 밀도 (spectral correlation density, $\mathrm{SCD}$ )를 이용하여 ATSC 디지털 텔레비전 신 호를 검출하기 위한 SCD 결합을 이용하는 스펙트럼 센싱 기법을 제시한다. ATSC 텔레비전 파일럿 신호의 사 이클로스테이셔너리 성질을 이용하는 검출 기법은 주로 특정 위치의 주파수의 $\mathrm{SCD}$ 값을 이용한다. 하지만, 다 중 경로 페이딩 환경에서 $\mathrm{SCD}$ 의 값이 여러 주파수에 걸쳐서 분포되어 있음을 확인할 수 있다. 파일럿 근처에 서 분포하는 일련의 $\mathrm{SCD}$ 값을 이용하기 위해 최대율 결합 (maximal ratio combining), 자승 결합 (square law combining), 균일 이득 결합 (equal gain combining)과 유사한 $\mathrm{SCD}$ 결합 기법들을 제안한다. 제시한 $\mathrm{SCD}$ 결합 기법은 다중 페이딩 환경하에서 검출 성능을 $0.5 \sim 1.0 \mathrm{~dB}$ 정도 향상시켰다.

\section{Abstract}

In this paper, we propose simple combining schemes for sensing ATSC digital television signals with spectral correlation density (SCD). The detection algorithms exploiting the cyclostationarity exhibited by the pilot of ATSC digital television signals usually use the SCD value at a given particular frequency. However, we found that non-zero SCDs are found to be distributed over a certain range of frequencies in multipath fading environment. To utilize a set of non-zero SCD values computed in the vicinity of the pilot location, we formulate a class of combining methods in analogy with the maximal ratio combining, the square law combining and the equal gain combining. We show that the proposed simple combining schemes improve the detection performance by $0.5 \sim 1.0 \mathrm{~dB}$ under multipath fading environments.

Key words : Cognitive radio(인지 무선), Spectrum sensing(스펙트럼 센싱), Spectral correlation density (스펙트럴 상관 밀도), Cyclostationary detection(사이클로스테이션너리 검출), ATSC DTV

I. Introduction

In the last several decades, we have witnessed revolutionary growth of wireless data traffic, which makes bandwidth efficiency ever more important. One of the boldest approaches for bandwidth efficiency

\footnotetext{
* 홍익대학교 전기전자공학부 (School of Electronic \& Electrical Engineering of Hongik University)

· 제1저자 (First Author) : 유도식(Do-Sik Yoo)

0 교신저자 (Corresponding Author) : 임종태(Jongtae Lim, Tel : +82-2-320-3053, email : jlim@hongik.ac.kr )

· 접수일자 : 2013년 5월 7일 · 심사(수정)일자 : 2013년 5월 7일 (수정일자 : 2013년 6월 21일) · 게재일자 : 2013년 6월 30일 http://dx.doi.org/10.12673/jkoni.2013.17.3.298
} 
enhancement is cognitive radio (CR) technology [1] which proposes to allow unlicensed access to a given spectrum when idle. Especially, a working group on wireless regional area networks (WRANs), IEEE 802.22 was established to develop the cognitive radio-based wireless WRAN standard to allow unlicensed access to unused spectrum in the television bands [2]. To realize cognitive radios, it is necessary to be able to detect the spectrum occupancy. In this paper, we consider simple combining schemes to enhance the performance of ATSC spectrum sensing with spectral correlation density (SCD) in multipath environments.

Spectrum sensing is one of the most challenging issues for implementing the $\mathrm{CR}$ systems. According to IEEE 802.22 requirements for the spectrum sensing of ATSC DTV signals, the miss detection probability should be less than 0.1 subject to a 0.1 false alarm probability when the signal-to-noise ratio (SNR) is -20.8 $\mathrm{dB}$. Various spectrum sensing techniques such as energy detection, pilot-based sensing, covariance-based sensing, cyclostationarity-based sensing and matched filter detection have been proposed [2]. Various aspects of these spectrum sensing methods are discussed in detail in the recent survey papers [3]-[5].

As noted in Annex $\mathrm{C}$ of [2], spectrum sensing techniques can be divided into signal-specific sensing and blind sensing. As the name indicates, blind sensing includes sensing techniques that do not require signal-specific features and often has the virtue of simplicity. The energy detector is one of the most important examples of blind sensing algorithms. In [6], it was shown that the optimal detector performance behaves like that of the energy detector at low SNR under certain generic conditions. However, it is possible to achieve performance better than energy detectors if the incumbent signal exhibits specific features. In the case of advanced television systems committee (ATSC) digital television (DTV) signals, such a signal specific feature is the pilot.

While many spectrum sensing algorithms fall short of the required performance, an algorithm that successfully exploiting the cyclostationarity exhibited by the pilot of ATSC DTV signals is proposed in [7]. They exploits the noise rejection property of the cyclostationary spectrum and determines the presence of cyclostationary signals by hypothesis testing based on the measurement of the cyclic spectrum of the received ATSC DTV signals. As presented in Annex $\mathrm{C}$ of [2] that has collected extensive spectrum sensing performance results proposed in the 802.22 working group, the algorithm proposed in [7] provides among the best performance. However, the performance of the algorithm still has some room for improvement particularly in multipath fading environment. For this reason, we consider simple combining techniques to improve the resilience to multipath fading of the algorithm proposed in [7].

We briefly review the concept of SCD in Section II. In Section III, we consider various combining schemes for performance enhancement. Next, we compare the performance of the proposed combining techniques in Section IV. Finally, we draw conclusions in Section V.

\section{SEPECTRAL CORRELATION DENSITY FUNCTION}

In this section, we briefly review the method of computing the SCD function introduced in [7]. Let $x(t)$ be a continuous-time real-valued signal and $x_{m}(t)$ denote the frequency-shifted version of $x(t)$ to have the carrier frequency $f_{\mathrm{IF}}+m \delta f$, where $f_{\mathrm{IF}}$ is the intermediate frequency, $m$ an integer, and $m \delta f$ a certain selected frequency resolution. To calculate SCDs in a practical digital system, we first sample the signal $x_{m}(t)$ with sampling period $T_{S}$ and obtain $N$ samples $x_{m}[0], x_{m}[1], \cdots, x_{m}[N-1]$ Next, its $N$-point discrete Fourier transform (DFT) defined as

$$
X_{m}[k]=\sum_{n=0}^{N-1} x_{m}[n] e^{-j 2 \pi k n / N}
$$


is computed. Then, the SCD at the discrete cycle frequency $d$ is calculated with a kind of spectral smoothing method by averaging $M$ spectral products as follow:

$$
S_{X}^{d}[l]=\sum_{m=-(M-1) / 2}^{(M-1) / 2} X_{m}[l+d] X_{m}^{*}[l-d],
$$

where the smoothing factor $M$ is assumed to be an odd number and the scaling factor $1 / M(N-1) T_{\mathrm{S}}$ is omitted for simplicity.

\section{SPECTRUM SENSING WITH COMBINED SCD}

The fundamental idea of cyclostationary spectrum sensing for ATSC DTV signals stems from the fact that the pilot tone leads to non-zero SCDs (at the zero frequency) unlike the case of pure additive white Gaussian (AWGN) noise. For this reason, [7] proposes to compare the absolute value of SCD at zero frequency with a suitably chosen threshold meeting a given false alarm level. In fact, it is possible to detect even a very weak pilot signal when the exact pilot location is known a priori. In practical system, it is necessary to repeat the threshold test over a certain frequency range because the exact pilot location is not known to the receiver for various reasons such as clock drift or Doppler shift. The process of repeating the threshold test over a range of frequencies leads to reduced threshold value for a given false alarm level and hence results in detection performance degradation. However, despite such performance degradation, the threshold test proposed by [7] still provides among the most promising detection performance as apparent from Annex $\mathrm{C}$ of [2].

In [7], the proposed algorithm was evaluated with 12 DTV signals captured in field measurements and recommended for performance evaluation by ATSC [8]. In this paper, we consider the same 12 signals for performance evaluation which were labeled as $\mathrm{A} \sim \mathrm{L}$ for notational simplicity as illustrated in Table 1.

While studying the performance behavior of the algorithm proposed in [7], we noted an interesting fact that the SCD is non-zero not only at a given particular frequency but also over a certain (probably small) range of frequencies in multipath environments. For example, let us consider the absolute value of the DFT of the two signals D and E depicted in Fig. 1. The DFTs $X_{D}[k]$ and $X_{E}[k]$ in Fig. 1 are obtained from 2048-point (frequency shifted and decimated) samples representing $19.03 \mathrm{msec}$. In Fig. 1, we observe that multiple peaks are observed in $X_{E}[k]$, while only a signal strong peak is present in $X_{D}[k]$. While the SCD at the pilot frequency appears to contain majority of the information in $X_{D}[k]$, only a small fraction of information can be captured with the single SCD at the pilot location in the case of $X_{E}[k]$. For this reason, we propose to use a set of SCD values computed in the neighborhood of the pilot location.

In [7], the absolute value of the SCD $S^{d}[0]$ of a given received signal computed at cyclic frequency $d$ is used to determine whether the pilot is present at frequency $d$. In this paper, we propose to use the

표 1. ATSC DTV 측정 신호

Table 1. ATSC DTV Captured Signals

\begin{tabular}{|c|c|}
\hline $\begin{array}{c}\text { Signal } \\
\text { Designation }\end{array}$ & ATSC DTV Captured Data File \\
Name
\end{tabular}




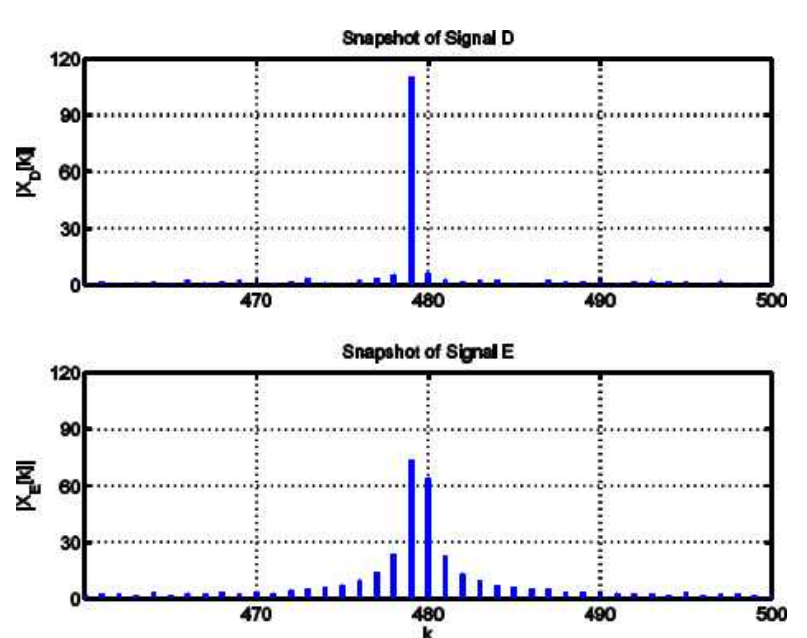

그림 1. 두 신호 D와 E에 대한 DFT

Fig. 1. DFT of the two signals $D$ and $E$

$2 L+1$ SCD values $S^{d-L}[0], S^{d-L+1}[0], \cdots$, $S^{d+L-1}[0], S^{d+L}[0]$ instead of a single SCD $S^{d}[0]$ to determine whether the pilot is dispersed in the neighborhood the frequency $d$. If the probability distributions of the $2 L+1$ SCDs are known under null (noise-only) and alternative (signal present) hypotheses, it is possible to consider a Neyman Pearson test. However, we note that the SCDs depend nontrivially on the channel characteristics and the noises. Moreover, it is often necessary to adopt simplicity for optimality. Consequently, instead of investigating the probabilistic characteristics of the $2 L+1$ SCDs, we consider simple methods to enhance the detection performance in this paper.

We consider a class of combining methods in which we use, for threshold test at frequency $d$, the statistics of the form

$$
T_{L}^{d}(\mathbf{w})=\operatorname{Re}\left[\sum_{l=-L}^{L} w_{l} S^{d+l}[0]\right]
$$

where $\operatorname{Re}[z]$ represent the real part of the complex number $z$. Of course, the threshold test must be repeated by changing the value of $d$ over a range of frequencies.

Instead of repeating the threshold test over the frequency range of interest, we may, equivalently, use the following statistic for one time threshold test:

$$
T_{L}(\mathbf{w})=\max _{d} \operatorname{Re}\left[\sum_{l=-L}^{L} \overline{w_{l}} S^{d+l}[0]\right]
$$

where $\overline{w_{l}}$ denotes the complex conjugate of $w_{l}$. We note that the performance will depend on the choice of the weighting vector $\left(w_{-L}, w_{-L+1}, \cdots, w_{L-1}, w_{L}\right)$. For this reason, we consider various methods to choose the weighting vector.

We first consider the weighting vector, in analogy with the maximal ratio combining [9], given by

$$
w_{l}=\frac{A_{l}}{\sqrt{\left|A_{-L}\right|^{2}+\left|A_{-L+1}\right|^{2}+\cdots+\left|A_{L-1}\right|^{2}+\left|A_{L}\right|^{2}}}
$$

where $A_{1}$ denotes the SCD $S^{d+l}[0]$ in the signal only situation. The resultant detection scheme shall be referred to as Setup1 in the following. The practical issue in the realization of this algorithm is in the estimation of $A_{l}$. As a simple estimate of $A_{l}$, we consider $S^{d+l}[0]$ (without assuming there is no noise) to study the degree of performance degradation with practical estimation schemes. This setup, equivalent to the square law combining, shall be referred to as Setup2.

Another weighting factor we consider is $w_{l}=A_{l} /\left|A_{l}\right|$ which is motivated by the equal gain combining scheme [6]. The resultant detection system shall be referred to as Setup3. Again, by replacing $A_{l}$ with $S^{d+l}[0]$ as in Setup2, we obtain the sum of $\left|S^{d+l}[0]\right|$ as the decision statistic, which we call Setup4. One drawback of Setup4 is that the detection threshold must be increased, with increased $L$ value, to keep the false level the same. To mitigate such an effect, we consider a positive sequence al that decreases as $|l|$ increases and choose

$$
w_{l}=a_{l} \cdot S^{d+l}[0] /\left|S^{d+l}[0]\right|
$$

as the weighting factor. This setup shall be referred to as Setup5. 


\section{SIMULATION RESULT}

In this section, we compare various the detection schemes considered in Section III. First, we describe the system model used for performance evaluation. As in [7], we use the 12 signals listed in Table 1 for test signals. Each of the 12 signals corresponds to one second of data sampled at $21.524476 \mathrm{MHz}$, which we divide into blocks of 409,600 samples corresponding to $19.03 \mathrm{msec}$. While we obtain 51 signal blocks, we only use the first 50 blocks for performance evaluation. According to the specification in [10], we pass each block through a 6-MHz bandpass filter and then normalize the signal strength. Here, we normalize the signal strength averaging over the 50 blocks rather than block by block. After normalization, each block is passed through a $40 \mathrm{kHz}$ bandpass filter around the pilot location and then down converted so that the specified pilot must lie at $23 \mathrm{kHz}$. Since the pilot location can shift from $23 \mathrm{kHz}$ for various reasons such as Doppler shift and clock drift, the pilot detection process is repeated over the frequency range between $13 \mathrm{kHz}$ and $33 \mathrm{kHz}$. The signal is then passed through a $50 \mathrm{kHz}$ lowpass filter and then decimated with 200:1 ratio to obtain $c[n]$ 's in Fig. 2. The noise samples $v[n]$ 's in Fig. 2 are generated in exactly the same manner with white noise input instead of the ATSC captured data. Finally, the noise corrupted signals $x[n]$ 's are obtained by adding $c[n]$ 's to $v[n]$ 's.

Now, we compare the performance of Setup1 Setup5 considered in Section III. For the reference, the detection scheme with the choice of $L=0$ is chosen as the baseline system and shall be referred to as Setup0. In Fig. 3, we showed the probability of miss detection of Setup0 at the false alarm level 0.1. We note that the probability of miss detection is less than 0.1 at $\mathrm{SNR}=$ $-20 \mathrm{~dB}$ for all 12 captured signals. In particular, we note that the probability of miss detection is less than 0.1 at $\mathrm{SNR}=-24 \mathrm{~dB}$ for signals except for $\mathrm{K}$ and $\mathrm{L}$.

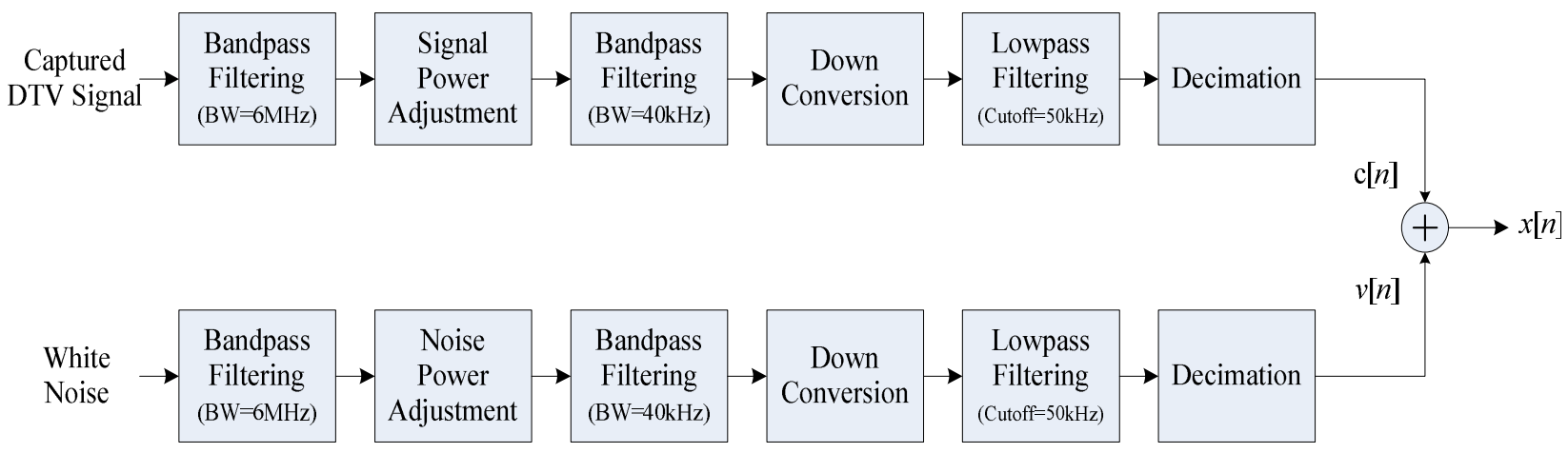

그림 2. ATSC DTV 신호 센싱을 위한 전처리

Fig. 2. Preprocessing for Sensing ATSC DTV Signals 


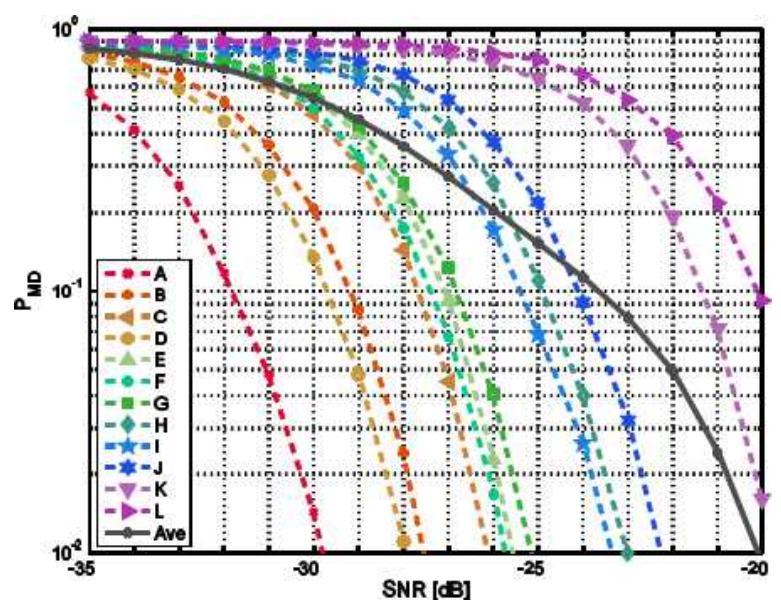

그림 3. Setup0의 성능 (기준 시스템)

Fig. 3. Performance of Setup0 (Baseline System)

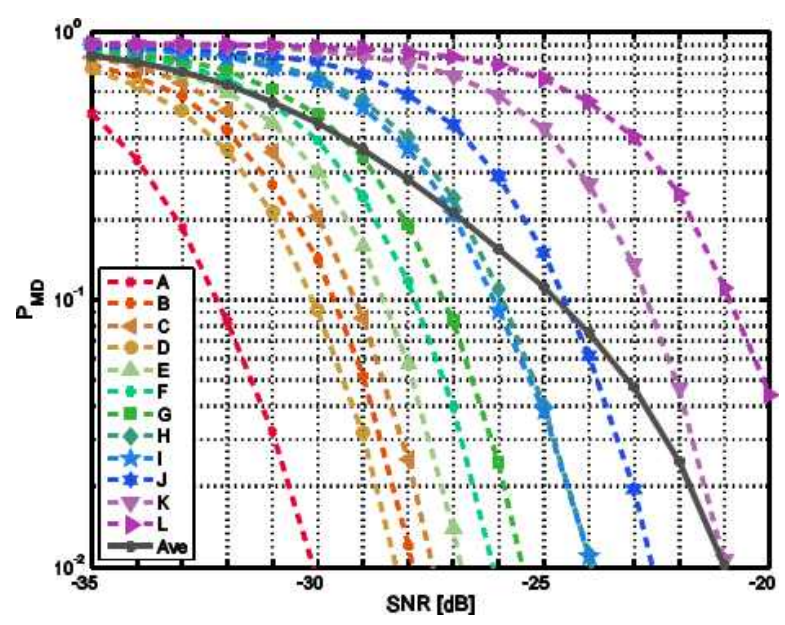

그림 4. Setup1의 성능

Fig. 4. Performance of Setup1

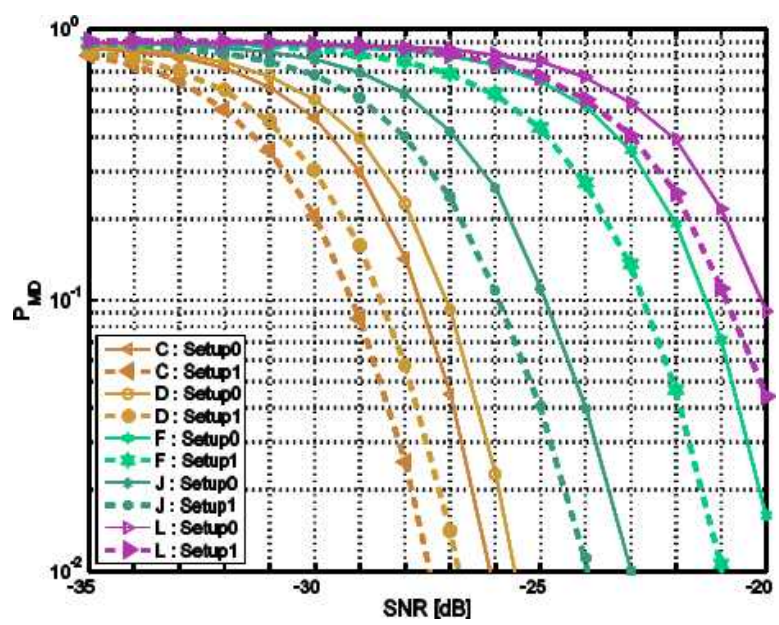

그림 5. 신호들의 성능 비교

Fig. 5. Performance Comparison for Selected Signals
표 2. 미검출 확률 0.1 을 위한 요구 SNR

Table 2. Required SNR for Missed Detection Probability 0.1

\begin{tabular}{|c|c|c|c|c|c|c|}
\hline Sig. & Setup0 & Setup1 & Setup2 & Setup3 & Setup4 & Setup5 \\
\hline A & -31.82 & -32.23 & -31.74 & -31.34 & -31.27 & -31.48 \\
\hline B & -29.19 & -29.65 & -29.39 & -29.20 & -29.20 & -29.39 \\
\hline C & -27.69 & -29.18 & -28.47 & -28.90 & -28.80 & -29.32 \\
\hline D & -29.71 & -30.11 & -29.64 & -29.25 & -29.10 & -28.84 \\
\hline E & -27.09 & -28.54 & -27.89 & -28.32 & -28.23 & -28.26 \\
\hline F & -27.42 & -27.85 & -27.52 & -27.23 & -27.29 & -27.44 \\
\hline G & -26.81 & -27.22 & -26.75 & -26.37 & -26.23 & -26.46 \\
\hline H & -24.91 & -25.91 & -25.53 & -25.83 & -25.76 & -25.82 \\
\hline I & -25.41 & -26.11 & -25.77 & -25.88 & -25.88 & -25.96 \\
\hline J & -24.11 & -24.54 & -24.15 & -23.76 & -23.81 & -23.98 \\
\hline K & -21.34 & -22.71 & -22.07 & -22.51 & -22.42 & -22.46 \\
\hline L & -20.10 & -20.89 & -20.56 & -20.71 & -20.68 & -20.76 \\
\hline Ave & -23.67 & -24.72 & -24.13 & -24.30 & -24.24 & -24.32 \\
\hline
\end{tabular}

Among the schemes Setup1 Setup5, Setup1 provides the best detection performance. In Fig. 4, the miss detection probability of Setup1 with $L=1$ is presented. We note that the average probability of miss detection with Setup1 is about $1 \mathrm{~dB}$ better than that of Setup0. However, upon closer comparison between Figs. 3 and 4, we observe that the performance is not uniformly enhanced over the 12 signals. For example, Setup1 is about $0.4 \mathrm{~dB}$ better than Setup0 for signal A while the gap grows to about $1.4 \mathrm{~dB}$ for signal $\mathrm{E}$.

For the detailed comparison between Setup 0 and Setup1, the performance of 5 selected signals is shown in Fig. 5. The performance enhancement, while nonuniform, can be important in satisfying worst case performance guarantee. For example, we note that Setup1 satisfies the original requirement [11] of probability of miss detection less than 0.1 at false alarm level 0.1 for all 12 signals at SNR less than $-20.8 \mathrm{~dB}$, while Setup0 fails to satisfy such a condition due to signal $\mathrm{L}$.

To save the space to present the performance of Setup2 $\sim$ Setup5, we collected, in Table 2, the required SNRs to achieve the miss detection probability of 0.1 at false alarm level 0.1 for the 12 signals. We have chosen 
$L=1$ for Setup2 and Setup4, and $L=2$ for Setup3 and Setup5. We note that Setup4 does not provide as good performance as Setup1. However, the performance gap of $0.4 \mathrm{~dB}$ appears to be reasonable since Setup4 does not need to estimate $A_{l}$. Moreover, Setup4 performance can be improved without the need to estimate as illustrated in Setup 5 performance in Table 2, for which $\left(a_{-1}, a_{0}, a_{1}\right)$ has been chosen to be $(0.75,1,0.75)$.

\section{CONCLUSTIONS}

We considered various combing schemes for ATSC DTV signal detection with SCD under multipath fading environment. It is showed that the detection performance can be enhanced by about $0.5 \sim 1.0 \mathrm{~dB}$ on the average. In particular, we found that simple sum of absolute values of SCDs leads to reasonably good performance without the need to implement estimation schemes and that the performance of such a scheme can even be enhanced with a judicious choice of weighting factors.

\section{Acknowledgment}

This research was supported by Basic Science Research Program through the National Research Foundation of Korea funded by the Ministry of Education (2010-0025062).

\section{References}

[1] J. Mitola III and G. Q. Maguire, "Cognitive Radio: Making Software Radios More Personal," IEEE Personal Communications, Vol. 6, No. 4, pp. 13-18, Aug. 1999.

[2] IEEE std. 802.22, "Cognitive Wireless RAN Medium Access Control (MAC) and Physical Layer (PHY) Specifications: Policies and Procedures for Operation in the TV Bands," IEEE standard 802.22, July 2011.

[3] A. Ghasemi and E. Sousa, "Spectrum Sensing in Cognitive Radio Networks: Requirements, Challenges and Ddesign Trade-offs," IEEE Communications Magazine, Vol. 46, No. 4, pp. 32-39, Apr. 2008.

[4] J. Ma, G. Li, and B. H. Juang, "Signal Processing in Cognitive Radio," Proceedings of the IEEE, Vol. 97, No. 5, pp. 805-823, May 2009.

[5] T. Yucek and H. Arslan, "A Survey of Spectrum Sensing Algorithms for Cognitive Radio Applications," IEEE Communications Surveys and Tutorials, Vol. 11, No. 1, pp. 116-130, quarter 2009.

[6] A. Shahi, N. Hoven, and R. Tandra, "Some Fundamental Limits on Cognitive Radio," in Proc. 42nd Annu. Allerton Conf. Communication, Control, and Comuting, Monticello, IL, pp. 1662-1671, Oct. 2004.

[7] H.-S. Chen, W. Gao, and D. Daut, "Spectrum Sensing Using Cyclostationary Properties and Applications to IEEE 802.22 WRAN," in Proc. IEEE Global Telecommunications Conference (GLOBECOM '07), pp. 3133-3138, Nov. 2007,

[8] ATSC std., "ATSC Recommended Practice: Receiver Performance Guidelines A/74," ATSC standard, Washington D.C., Jun. 2004.

[9] J. Proakis and M. Salehi, Digital Communications, 5th ed., McGraw-Hill, 2008.

[10] S. Mathur, R. Tandra, S. Shellhammer, and M. Ghosh, "Initial Signal Processing of Captured DTV Signals for Evaluation of Detection Algorithms," IEEE 802.22-06/0158r5, Sep. 2006.

[11] C. R. Stevensen, C. Cordeiro, E. Sofer, and G. Chouinard, "Functional Requirements for the 802.22 WRAN Standard," IEEE 802.22-05/0007r45, Sep. 2005. 
유 도 식 (Do-Sik Yoo)

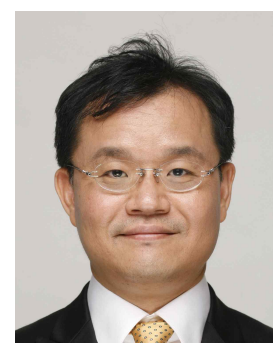

1990년 8월 : 서울대학교 전기공학과 (공학사)

1994년 2월 : 서울대학교 물리학과

(이학석사)

2002년 4월 :미국 미시간대학교

전기공학과(공학박사)

2002년 2월 2003년 10월 미시간대학교

박사 후 연구원

2006년 9월 현재 홍익대학교 전자전기공학부 부교수 관심분야 : 통신이론, 무선통신 시스템 설계, 정보이론, 부호이론, 네트워크 정보이론 등
임 종 태 (Jongtae Lim)

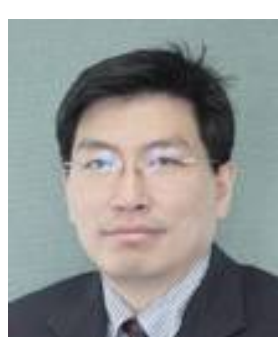

1989년 2월 : 서울대학교 전자공학과 (공학사)

1991년 2월 : 서울대학교 전자공학과 (공학석사)

2001년 8월 : The Univ. of Michigan at Ann Arbor 전기공학과(공학박사) 1991년 3월 2004년 8월 (주) 대우 일렉트로닉스 영상연구소 및 신호처리연구소 책임 연구원 2004년 9월 2008년 2월 한국항공대학교 항공전자 및 정보통신공학부 조교수 2008년 3월 현재 홍익대학교 전자전기공학부 부교수 관심분야 : 디지털 통신 및 방송 시스템, 디지털 신호 처리 